\title{
Imogen 38: A Novel 38-kD Islet Mitochondrial Autoantigen Recognized by T Cells from a Newly Diagnosed Type 1 Diabetic Patient
}

\author{
Susan D. Arden, ${ }^{\star}$ Bart O. Roep, ${ }^{\ddagger}$ Pavlos I. Neophytou, ${ }^{\star}$ Elena F. Usac, ${ }^{,}$Gaby Duinkerken, ${ }^{\ddagger}$ René R. P. de Vries, ${ }^{\ddagger}$ \\ and John C. Hutton* \\ *Department of Clinical Biochemistry, University of Cambridge, Addenbrooke's Hospital, Cambridge CB2 2QR, United Kingdom; \\ and ${ }^{\ddagger}$ Immunohaematology and Bloodbank, University Hospital, 2300RC Leiden, The Netherlands
}

\begin{abstract}
Cell-mediated autoimmune attack directed against islet proteins of $\sim 38 \mathrm{kD}$ in size has been associated with type 1 diabetes. A novel murine cDNA encoding an antigen of this size was cloned using a screening procedure based on the proliferative response of a human diabetic $T$ cell clone (1C6) to a recombinant antigen epitope library. Membrane preparations from COS 7 cells transfected with the fulllength 1,267-bp cDNA elicited a proliferative response from the reporter $T$ cells comparable to that of the defined peptide epitope and native insulinoma antigen. In vitro translation and transfection experiments suggested that the protein is initially synthesized as a $44-\mathrm{kD}$ protein and then processed to the native $38-\mathrm{kD}$ form through the proteolytic removal of a 54-aa $\mathrm{NH}_{2}$-terminal mitochondrial targeting sequence. Differential centrifugation, Percoll density gradient centrifugation, and immunofluorescence studies confirmed localization of the antigen to mitochondria. Northern blot, Western blot, and 1C6 T cell proliferation assays showed that, although imogen 38 was more highly expressed in $\beta$ cell than $\alpha$ cell lines, it was also present in other tissues. It is concluded that imogen $\mathbf{3 8}$ may be a target for bystander autoimmune attack in diabetes rather than a primary autoantigen. (J. Clin. Invest. 1996. 97:551-561.) Key words: diabetes • autoimmunity $\bullet$ insulin-dependent diabetes mellitus $\bullet$ mitochondria $\bullet$ islet
\end{abstract}

\section{Introduction}

Type 1 diabetes (insulin-dependent diabetes mellitus) results from cell-mediated autoimmune attack directed towards the islets of Langerhans, which culminates in the specific destruction of the pancreatic $\beta$ cell. Serological studies on newly diagnosed type 1 diabetic patients and prediabetic genetically susceptible experimental animals indicate that multiple molecular targets for autoreactive antibodies exist (1). These include in-

Address correspondence to Dr. John C. Hutton, Barbara Davis Center for Childhood Diabetes, University of Colorado Health Sciences Center, 4200 East 9th Avenue, Box B140, Denver, CO 80262. Phone: 303-270-4128; FAX: 303-270-4124. P. I. Neophytou's present address is The Cyprus Institute of Neurology and Genetics, POB 3462, Nicosia, Cyprus.

Received for publication 1 August 1995 and accepted in revised form 14 November 1995.

J. Clin. Invest.

(C) The American Society for Clinical Investigation, Inc.

$0021-9738 / 96 / 01 / 551 / 11 \$ 2.00$

Volume 97, Number 2, January 1996, 551-561 sulin (2) and carboxypeptidase $\mathrm{H}$ (3), which are localized to the secretory granule lumen; glutamate decarboxylase (GAD) ${ }^{1}$ (4) and ICA69 (5), which have a cytosolic or peripheral membrane association; ICA 512 (6) and the non-GAD 64-kD antigen (7), which are integral membrane proteins; and peripherin (8), a cytoskeletal component. To what extent the diversity in molecular character and intracellular localization of the autoantigens is a reflection of determinant spreading or secondary autoimmune phenomena is unclear.

The molecular targets of autoreactive $\mathrm{T}$ cells in diabetes overlap to some extent with those recognized by autoantibodies, as indicated by the finding that $\mathrm{T}$ cell antigen recall responses can be elicited to purified GAD, insulin, and carboxypeptidase $H$ (9-12). The majority of $T$ cell responses in spontaneously diabetic animals or humans, however, appears to be to unidentified proteins of a broad range of molecular sizes (13-16). Subcellular fractionation studies have suggested that the insulin-secretory granule may be a major source of such antigens (17-20).

We have shown that peripheral $\mathrm{T}$ cells from a large proportion of newly diagnosed type 1 human diabetics respond to crude insulinoma-secretory granule (ISG) preparations (16) and that membrane antigens in the size range of 36-40 kD may be important to this response (21). The presence of circulating antibodies to proteins of $38 \mathrm{kD}$ in human (7) (22-24) and experimental diabetes $(25)$ and the production of $38-\mathrm{kD}$ responsive $\mathrm{T}$ cell lines from spontaneously diabetic nonobese diabetic mice (19) further suggest that autoantigens of this molecular size are significant. We have generated a cytotoxic $38-\mathrm{kD}$ reactive $\mathrm{CD}^{+} \mathrm{T}$ cell clone (1C6) from PBMCs of a newly diagnosed type 1 diabetic patient using several rounds of in vitro stimulation with a crude membrane fraction of Rin m5F insulinoma cells (18). The epitope seen by clone 1C6 was recently mapped to a 70-aa fragment of an unidentified insulinoma protein by screening a subtracted cDNA fragment expression library (26). Subsequent fine mapping with synthetic peptides and molecular modeling have defined the minimal epitope as the 11-aa sequence, SLWEIEFAKQL.

We report here the isolation of the corresponding fulllength cDNA from a mouse $\beta$ TC 3 insulinoma cDNA library, demonstrate its authenticity based upon its expression in prokaryote and eukaryote systems, and document its tissue and subcellular distribution using antibodies generated to the recombinant antigen. The antigen, which is termed imogen 38, appears to be a novel minor mitochondrial protein of variable but broad tissue distribution.

1. Abbreviations used in this paper: GAD, glutamic acid decarboxylase; GST, glutathione $S$-transferase; ISG, insulinoma-secretory granule. 


\section{Methods}

Unless otherwise stated, all molecular cloning procedures were performed by standard protocols (27). Initial cloning of a cDNA fragment encoding the $38-\mathrm{kD}$ antigenic target was achieved by using the proliferative response of the T cell clone 1C6 to screen a cDNA expression library prepared from a subtraction of mouse insulinoma $\beta T C 3$ with mouse glucagonoma $\alpha \mathrm{TC} 2 \mathrm{cDNA}(26,28)$. The 211-bp insert in the positive clone $(31 \mathrm{G})$ was radiolabeled by random priming (oligolabeling kit; Pharmacia, Uppsala, Sweden) with $\left[\alpha^{-32} \mathrm{P}\right] \mathrm{dCTP}$ (Amersham International, Little Chalfont, UK) and used to screen a full-length cDNA library prepared from mouse Rip Tag insulinomas in the plasmid vector pSVSPORT $(29,30)$. Sequencing was performed in both directions by the Sanger dideoxy chain termination method on double-stranded templates using synthetic oligonucleotide primers (31).

An EcoRI fragment spanning residues -9 to 946 of the cDNA (aa 1-315) (Fig. 1) was inserted into the pGEX-1 vector (32) to generate a glutathione $S$-transferase (GST) fusion protein. The full-length protein was also expressed in Escherichia coli as an $\mathrm{NH}_{2}$-terminal His $_{6}$-tagged construct in pRSET B (Invitrogen Corp., Abingdon, UK) and in COS 7 cells using a cytomegalovirus promoter construct in pCDNA3 (Invitrogen Corp.). In both instances, the KpnI and HindIII sites in the original pSVSPORT vector were used for subcloning. Bacterial GST fusion proteins were purified by preparation of inclusion bodies (33) followed by SDS-PAGE and electroelution with an Extraphor apparatus (LKB, Stockholm, Sweden). Bacterial His $6^{-}$ tagged proteins were purified by metal chelate chromatography $\left(\mathrm{Ni}^{2+}\right.$ nitrilotriacetic acid agarose; QIAGEN Inc., Chatsworth, CA) under denaturing conditions ( $8 \mathrm{M}$ urea, $50 \mathrm{mM}$ Tris, $10 \mathrm{mM}$ mercaptoethanol, $\mathrm{pH} 8$ ), and elution was achieved with $150 \mathrm{mM}$ imidazole in the same buffer. The protein was extensively dialyzed, initially against PBS containing $1 \mathrm{mM}$ mercaptoethanol and then against PBS alone.

Rat insulinomas were propagated by subcutaneous transplantation in New England Deaconess Hospital rats and homogenized with a Dounce homogenizer in $0.3 \mathrm{M}$ sucrose, $10 \mathrm{mM}$ MES $\mathrm{K}^{+}, 2 \mathrm{mM}$ EGTA, and $1 \mathrm{mM} \mathrm{MgSO}_{4}, \mathrm{pH} 6.5$, at $4^{\circ} \mathrm{C}$ as previously described (34). The homogenate was centrifuged at $500 \mathrm{~g}$ for $10 \mathrm{~min}$, the pellet was rehomogenized twice and centrifuged under the same conditions, and the pooled supernatants were then subjected to sequential centrifugation at $4^{\circ} \mathrm{C}$ at $1,700 \mathrm{~g}$ for $10 \mathrm{~min}, 3,000 \mathrm{~g}$ for $20 \mathrm{~min}, 30,000 \mathrm{~g}$ for $20 \mathrm{~min}$, and 300,000 $\mathrm{g}$ for $60 \mathrm{~min}$. The 30,000-g pellet was resuspended in $6 \mathrm{ml}$ homogenization medium, and $2.5 \mathrm{ml}$ was mixed with $7.5 \mathrm{ml}$ $36 \%$ (vol/vol) Percoll (Sigma Chemical Co., St. Louis, MO) containing $2 \mathrm{mM}$ EGTA, $1 \mathrm{mM} \mathrm{MgSO}_{4}$, and $10 \mathrm{mM} \mathrm{MES} \mathrm{K}^{+}$, pH 6.5, and centrifuged for $45 \mathrm{~min}$ at 25,000 $\mathrm{g}$ in a rotor (Sorvall T1270; Dupont, Stevenage, UK). The gradient was divided into 10 fractions, and particulate material was recovered by repeated dilution of each fraction with $3 \mathrm{vol}$ homogenization media followed by centrifugation at 30,000 $g$ for $20 \mathrm{~min}$ in a rotor (SW50.1; Beckman Instruments, Inc., Spinco Division, Palo Alto, CA). The differential and density gradient centrifugation fractions were assayed for $1 \mathrm{C} 6 \mathrm{~T}$ cell proliferative activity and for a series of organelle marker proteins, namely insulin (granules) (34), cytochrome oxidase (mitochondria) (35), aryl sulphatase (lysosomes) (36), and alkaline phosphatase (plasma membrane) (37). Western blot analyses were performed using antisera to either carboxypeptidase $\mathrm{H}$ (38) or recombinant $38 \mathrm{kD}$ (1C2).

Tissue culture cell lines were grown to subconfluency in DME containing $10 \%$ newborn calf serum, rinsed extensively in PBS, scraped off the tissue culture dish in $1 \mathrm{ml}$ ice-cold $10-\mathrm{mM}$ Tris-HCl, 1 mM EDTA, pH 8, sonicated for $20 \mathrm{~s}$ (MSE Soniprep, Crawley, UK), and then centrifuged at $20,000 \mathrm{~g}$ for $30 \mathrm{~min}$ in a refrigerated microcentrifuge to obtain a supernatant (soluble) and particulate fraction. Mouse tissues were transferred immediately into liquid nitrogen and pulverized while frozen with a mortar and pestle, and $100 \mathrm{mg}$ wet wt samples were then sonicated and centrifuged as above.

Total RNA was prepared by homogenization of tissue in $6 \mathrm{M}$ guanidinium $\mathrm{HCl}, 8 \%$ (wt/vol) mercaptoethanol, and $2 \%$ (vol/vol) laurylsarkosinate, followed by $\mathrm{CsCl}$ step-gradient centrifugation (39). Poly $\mathrm{A}^{+}$mRNA was then prepared by oligo dT cellulose chromatography, and samples were analyzed by Northern blotting after electrophoresis on denaturing formaldehyde gels. Blots were hybridized for $16 \mathrm{~h}$ at $42^{\circ} \mathrm{C}$ in $50 \%$ (vol/vol) formamide, $5 \times$ sodium chloride sodium phosphate EDTA buffer (SSPE), $5 \times$ Denhardt's reagent, and $50 \mu \mathrm{g} /$ $\mathrm{ml}$ salmon testis DNA and finally washed in $0.1 \times \mathrm{SSPE}, 0.1 \%$ SDS at $55^{\circ} \mathrm{C}$. ${ }^{32} \mathrm{P}$-radiolabeled randomly primed probes were generated from the 955-bp EcoRI fragment in the pSVSPORT clone $1 \mathrm{C} 2$ and from mouse actin. Gel loadings were adjusted on the basis of actin probe hybridization to the samples subject to RNA dot blot analysis. Visualization and quantitation of blots was performed by phosphorimaging (BAS 2000; Fuji, Sheffield, UK).

In vitro translation analyses were performed with SP6 RNA polymerase transcripts of clone $1 \mathrm{C} 2$ and $9 \mathrm{~B} 2(0.1 \mu \mathrm{g} / 25 \mu \mathrm{l}$ incubation $)$ in a reticulocyte lysate/dog pancreatic microsome system (Promega, Madison, WI). The efficiency of translocation of the products into the lumen of the endoplasmic reticulum was assessed by incubation for 30 min at $4^{\circ} \mathrm{C}$ with $10 \mu \mathrm{g} / \mathrm{ml}$ proteinase $\mathrm{K}$. $\left[{ }^{35} \mathrm{~S}\right]$ Methionine-labeled products were analyzed by SDS-PAGE on $12.5 \%$ (wt/vol) acrylamide $0.1 \%$ bis-N, $\mathrm{N}^{\prime}$-bisacrylamide gels and prepared for fluorography (38) or analyzed by phosphorimaging after drying.

$\mathrm{T}$ cell proliferation assays were performed using $1-2 \times 10^{4} \mathrm{~T}$ cells and 5-10 $\times 10^{4}$ irradiated HLA-DR-matched PBMCs (antigen-presenting cells) in flat-bottomed 96-well plates in complete Iscove's modified Dulbecco's medium (18). PHA (250 ng/ml) and IL-2 (recombinant, $10 \%$ Lymphocult; Biotest, Dreieich, Germany) were used as positive controls along with $2-10 \mu \mathrm{g} / \mathrm{ml}$ crude ISG (18). Tissue samples and subcellular fractions prepared as above were irradiated to ensure sterility and analyzed at a range of concentrations (0.1-50 $\mu \mathrm{g} / \mathrm{ml})$.

Subconfluent cultures of COS 7 cells (3.5-cm dishes) were transfected with $1 \mu \mathrm{g} 1 \mathrm{C} 2 \mathrm{cDNA}$ in pCDNA3 using the reagent Lipofectamine (GIBCO BRL, Paisley, UK) according to the manufacturer's recommended procedure. Cells were grown for a further $24-48 \mathrm{~h}$ and then extracted in ice-cold $10-\mathrm{mM}$ Tris- $\mathrm{HCl}, 1 \mathrm{mM}$ EDTA, $\mathrm{pH} 8$, for the T cell proliferation assay or Western blotting as above, or were fixed in situ with $4 \%$ (wt/vol) paraformaldehyde in PBS for indirect immunofluorescence microscopy. In the latter case, cells were permeabilized with $0.1 \%$ Triton X-100 in PBS and then incubated with affinity-purified rabbit antibody (equivalent to 1:50 diluted serum) for $1 \mathrm{~h}$ at room temperature in $0.1 \mathrm{M}$ glycine, $0.5 \%$ nonimmune horse serum in PBS, followed by fluorescein-conjugated pig anti-rabbit IgG (1:500; DAKO, Copenhagen, Denmark) for $1 \mathrm{~h}$. Double-immunofluorescence labeling was performed by the simultaneous addition of mouse mAb (1:100) to a $65-\mathrm{kD}$ human mitochondrial protein clone 2D1/82 (Biogenesis Ltd, Poole, UK) followed by Texas Red-conjugated sheep anti-mouse IgG (1:100; Amersham International) for $1 \mathrm{~h}$.

Antibodies to the GST-1C2 fusion protein were preabsorbed with bacterial homogenate prepared from cells expressing wild-type GST, and then affinity-purified on the full-length His-tagged antigen transferred to nitrocellulose membranes (40). Western blotting was performed as previously described (38) using horseradish peroxidase-conjugated second antibody (DAKO) and enhanced chemiluminescence (Amersham International) as the detection system. Protein was determined with bicinchoninic acid reagent (Pierce, Rockford, IL) using BSA as standard. Samples were incubated at $60^{\circ} \mathrm{C}$ for 10 min in $10 \mu \mathrm{l} \%$ (wt/vol) SDS to solubilize membrane proteins or inclusion bodies before assay. Computational analyses were performed with the Genetics Computer Group (WI) package via the Human Genome Mapping Project (Sanger Centre, Hinxton, UK).

\section{Results}

Cloning and expression of the 38-kD antigen. 13 independent clones (7 between 1,231-1,267 bp) were obtained from screen- 


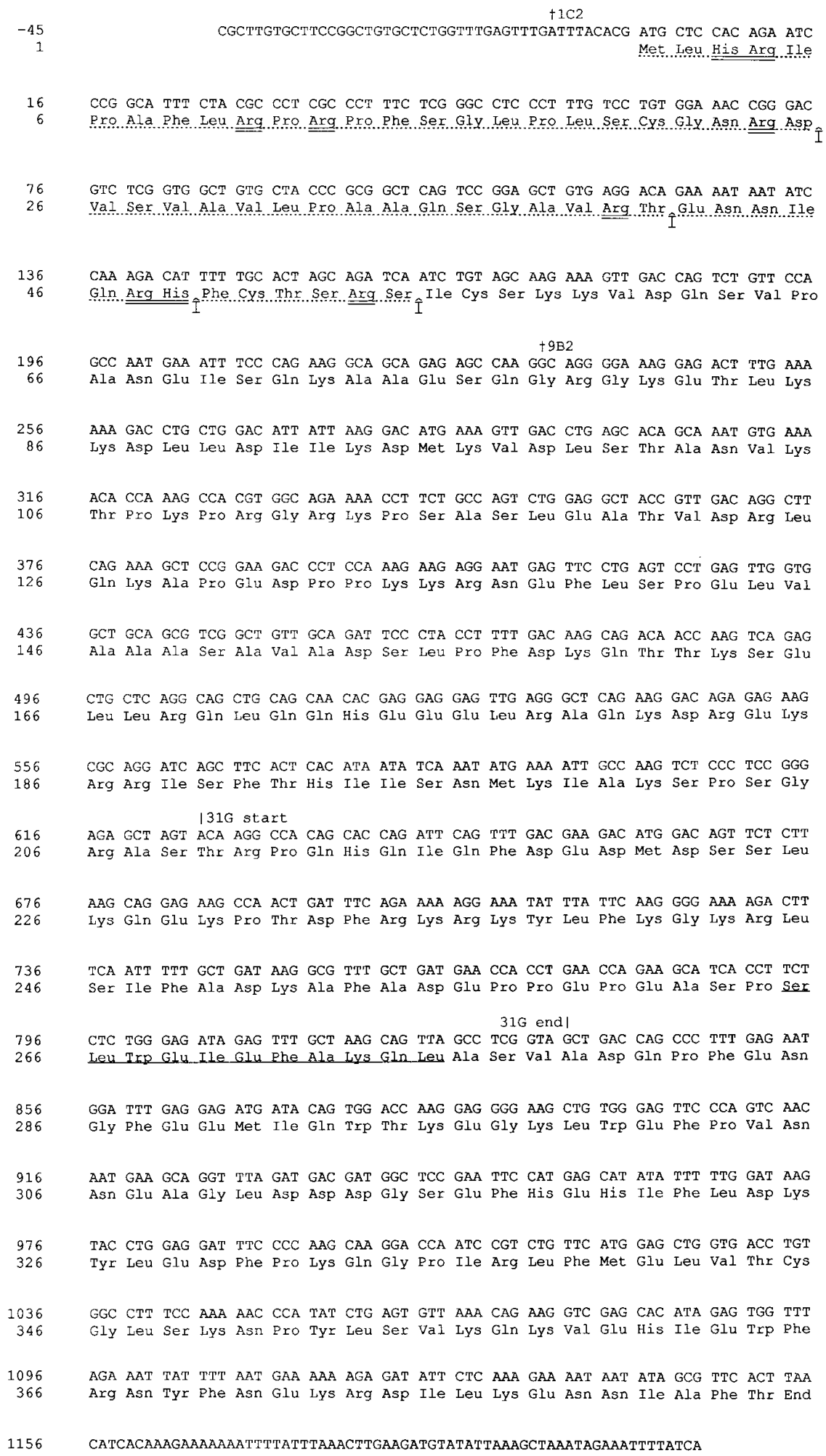

Figure 1. Nucleotide and deduced amino acid sequence of cloned 38-kD antigen. The putative mitochondrial import sequence is indicated by a dotted underline with the position of positively charged residues double underlined. Potential cleavage sites of the mitochondrial matrix-processing peptidase are also shown (ÎI). The start (nt 626) and end (nt 835) of the 211-bp probe fragment $31 \mathrm{G}$ are indicated above the nucleotide sequence, and the minimal antigenic epitope is underlined. The starting positions of two sequences subcloned into prokaryote and eukaryote expression vectors are indicated above the nucleotide sequence. The nucleotide sequence information has been deposited with European Bioinformatics Institute (EBI) for in clusion in Genbank and EMBL databases and is available under accession number Z46966. ing $2 \times 10^{5}$ colonies. All of these were judged to be derived from the same mRNA based from the sequence at their $5^{\prime}$ and $3^{\prime}$ ends (150-250 bp) and by restriction mapping with a panel of six cutter restriction endonucleases. The longest clone (1,267 bp; Fig. 1) was sufficiently large with the addition of a poly $\mathrm{A}^{+}$tail (typically $>150 \mathrm{bp}$ ) to account for the size of the endogenous mRNA (1,500 bp; see Fig 8). The first AUG codon in this sequence bore a consensus Kozak motif and was shown to be a functional start site for in vitro translation (Fig. 2). The translational product was of sufficient size to incorporate the sequence of the native antigen (see below). From these data and structural features of the open reading frame described below, the sequenced clone was judged to be full length.

The first 25 aa of the $\mathrm{NH}_{2}$ terminus of the deduced 384-aa translation product contained five positively charged amino 


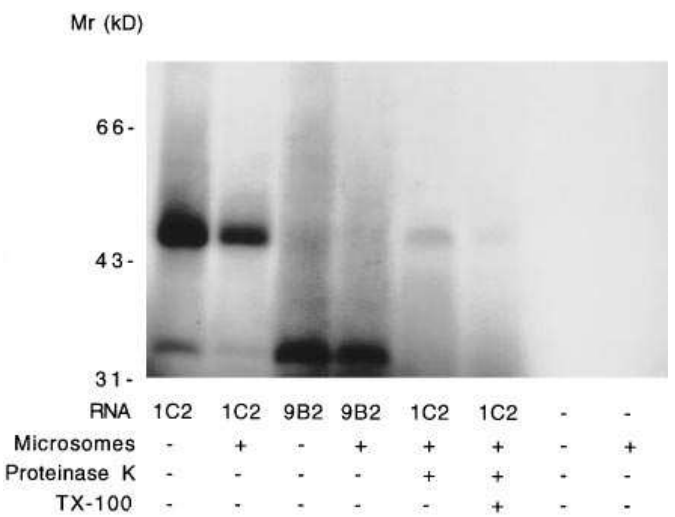

Figure 2. In vitro translation of the cloned cDNA. RNA transcripts of clones $1 \mathrm{C} 2$ and 9B2 were performed in the presence or absence of dog pancreatic microsomes and subsequently treated with proteinase $\mathrm{K}$ in the presence or absence of detergents to determine the extent of protection afforded by translocation into the lumen of the endoplasmic reticulum.

acids (4 Arg, $1 \mathrm{His),} 16$ hydrophobic residues, and a single negatively charged residue at position 25 . The positioning of the various Arg residues argued against this sequence functioning as a secretory protein signal sequence but was compatible with a mitochondrial import signal, which is typified by a positively charged amphipathic sequence and the general absence of acidic residues (41). A potential cleavage site for a mitochondrial processing peptidase $\left(\operatorname{Arg}_{24} \mathrm{Asp}_{25}\right)$ was located at the $\mathrm{COOH}$ terminus of this sequence. This was followed by a hydrophobic stretch spanning 14 aa and further potential cleavage sites for the mitochondrial processing peptidase complex at Arg $\mathrm{Thr}_{41}, \mathrm{Arg} \mathrm{His}_{48}$, or Arg $\mathrm{Ser}_{54}$.

The sequence of the $31 \mathrm{G}$ probe that was used to screen the cDNA library appeared in the central region of the molecule (nt 625-835) flanked by RsaI and AluI sites consistent with the original subtraction cloning procedure (42), which used PCR amplification of doubly digested fragments of $\beta$ TC 3 cDNA. The corresponding sequence of the full-length clone was identical to that reported previously except at nucleotide positions $629(\mathrm{G} \rightarrow \mathrm{A}), 675(\mathrm{~T} \rightarrow \mathrm{C}), 702(\mathrm{~A} \rightarrow \mathrm{T})$, and $740(\mathrm{~T} \rightarrow \mathrm{C})$, which resulted in amino acid changes at positions 211 ( $\mathrm{Arg} \rightarrow$ Lys), 234 (Arg $\rightarrow$ Ser), and 245 (Ile $\rightarrow$ Thr). These differences may be the result of either natural polymorphisms or infidelities in the multiple PCR reactions used in the original subtraction cloning procedure. The fact that the $5^{\prime}$ and $3^{\prime}$ sequences of the 13 independent clones appeared to be derived from the same mRNA argued against there being multiple isoforms of the protein within the $\beta$ cell. The antigen epitope that had been mapped using synthetic peptides was in the expected reading frame and orientation in the cloned sequence (aa 266275). Neither the nucleotide nor the protein sequence encoded by the cloned cDNA showed remarkable homology to cDNA sequences deposited in GENBANK, EMBL, PIR, or SWISSPROT data bases using FASTA, BLAST, and MOTIF algorithms.

In vitro translation of the sequence (clone 1C2; Fig. 1) generated a 44-kD protein consistent with the calculated $M_{\mathrm{r}}$ (43,887 D) of the 1,152-bp open-reading frame (Fig. 2). This product is significantly larger than the rat insulinoma protein (38 kD) identified on the basis of the T cell 1C6 proliferative response to electroeluted proteins or mouse antigen detected by Western blotting (see below). This raised the question of whether an alternate translation initiation site could be used or whether co- or posttranslational proteolysis of the protein occurs in vivo. The addition of dog pancreatic microsomes to an assay translating $1 \mathrm{C} 2 \mathrm{cRNA}$ did not affect the size of the translation product or protect it from digestion by proteinase $\mathrm{K}$ added at the end of the translation reaction. It was therefore unlikely that the protein was translocated into the lumen of the endoplasmic reticulum. A 5'-truncated cRNA (clone 9B2) that contained the second AUG codon with a Kozak consensus sequence was translated but with a lower efficiency than clone $1 \mathrm{C} 2$. The resultant protein was smaller in size $(33 \mathrm{kD})$ than the major form of the native antigen, although it did correspond in size to one of the minor immunoreactive forms of the antigen visualized by Western blot analyses (see below).

A bacterially expressed protein of the cloned sequence generated as a GST hybrid (aa 1-315) stimulated the proliferation of the $\mathrm{CD}^{+} \mathrm{T}$ cell clone 1C6 in the presence of HLADR1 antigen-presenting cells (Fig. 3). The response was of the same approximate magnitude and molar dose response as seen with a synthetic 20 -mer peptide incorporating the epitope (aa 259-278) (26). A GST construct of clone 9B2 and a histidinetagged full-length construct of $1 \mathrm{C} 2$ (aa 1-384) produced similar responses, whereas the corresponding fusion partners prepared from wild-type pGEX1 and pRSET B vectors were inactive in the assay (maximal stimulation index $<3$; data not shown). Native antigen in the form of a crude secretory granule fraction from rat insulinoma (45,000-g pellet) produced a similar maximal proliferative response to the recombinant Histagged construct and the synthetic antigen. At submaximal concentrations, the response to the native antigen and synthetic peptide was additive (data not shown). It is concluded that the cloned sequence represented the authentic precursor of the 38-kD antigen.

Subcellular localization of the 38-kD antigen. Differential centrifugation analyses of an insulinoma homogenate prepared under isotonic conditions (Fig. 4) showed that the 1C6 T cell reactivity was pelleted completely at $30,000 \mathrm{~g}$ for $20 \mathrm{~min}$ and was recovered in high yield and specific activity in a frac-

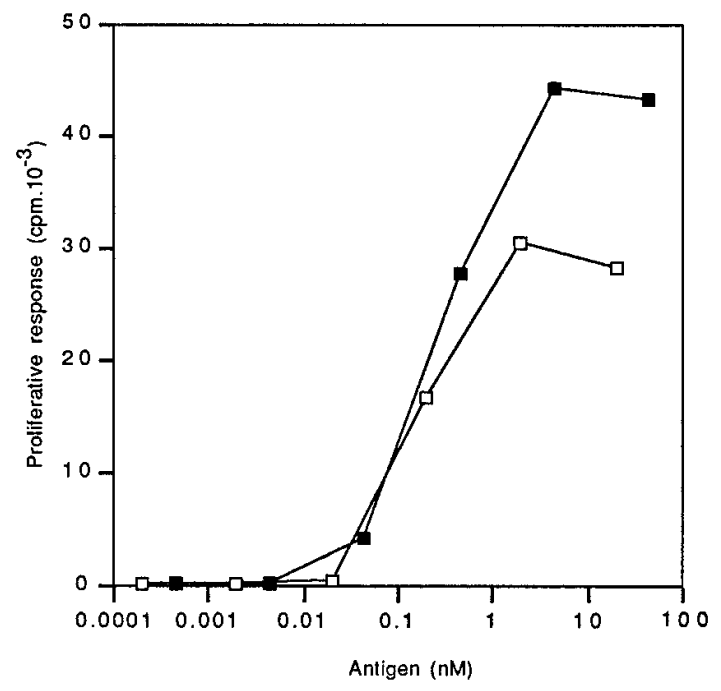

Figure 3. T cell clone 1C6 proliferative response to recombinant antigens. Results are shown for the GST fusion protein of aa 1-315 ( $\square$ ) and a synthetic 20-aa peptide (aa 259-278) (ם) bearing the epitope. 

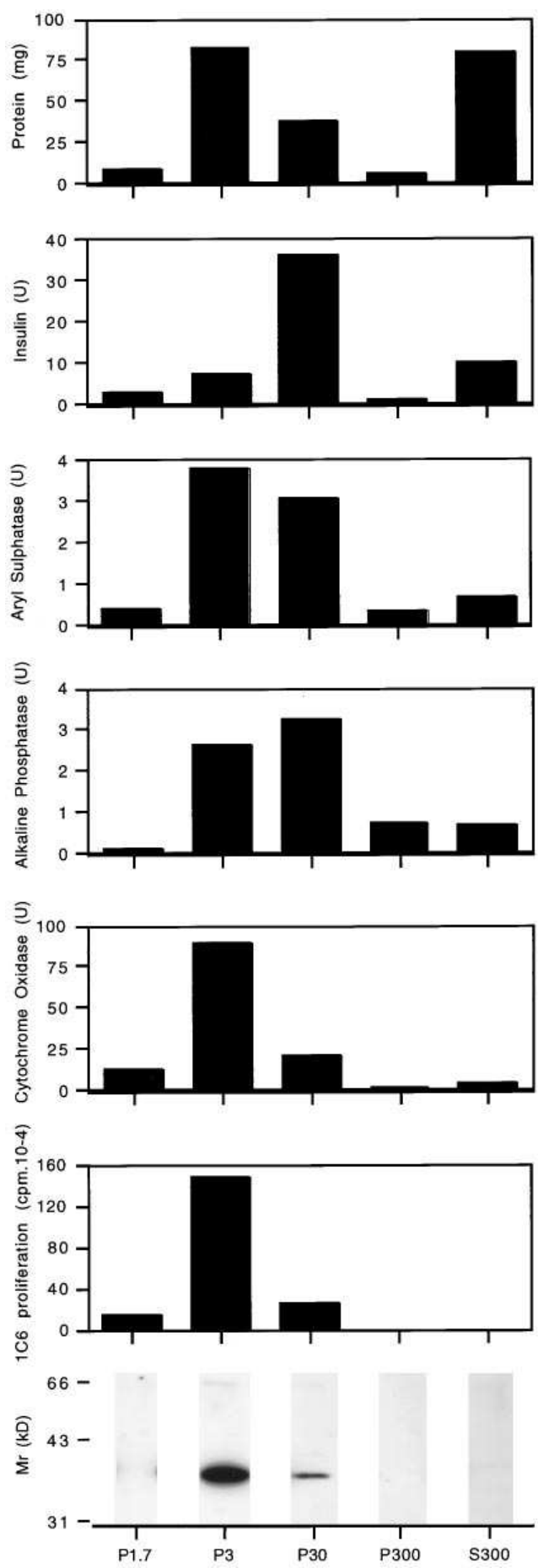

Figure 4. Differential centrifugation analysis of the subcellular distribution of the $38-\mathrm{kD}$ antigen in insulinoma tissue. A postnuclear supernatant from a rat insulinoma homogenate in isotonic medium was subjected to successive centrifugation steps to yield a 1,700- $g \times 10$ min pellet (P1.7), a 3,000- $g \times 20 \mathrm{~min}$ pellet (P3), a 30,000- $g \times 20 \mathrm{~min}$ pellet (P30), and a 300,000- $g \times 60$ min pellet (P300) and supernatant (S300). Each fraction was assayed for organelle marker proteins and a 1C6 reactivity as indicated on the y-axes; Western blot analyses were performed with affinity-purified guinea pig anti-38-kD proteins. In the latter two assays, the quantity of protein used in each assay was proportionate to the total protein recovered in each fraction as shown in the uppermost panel.
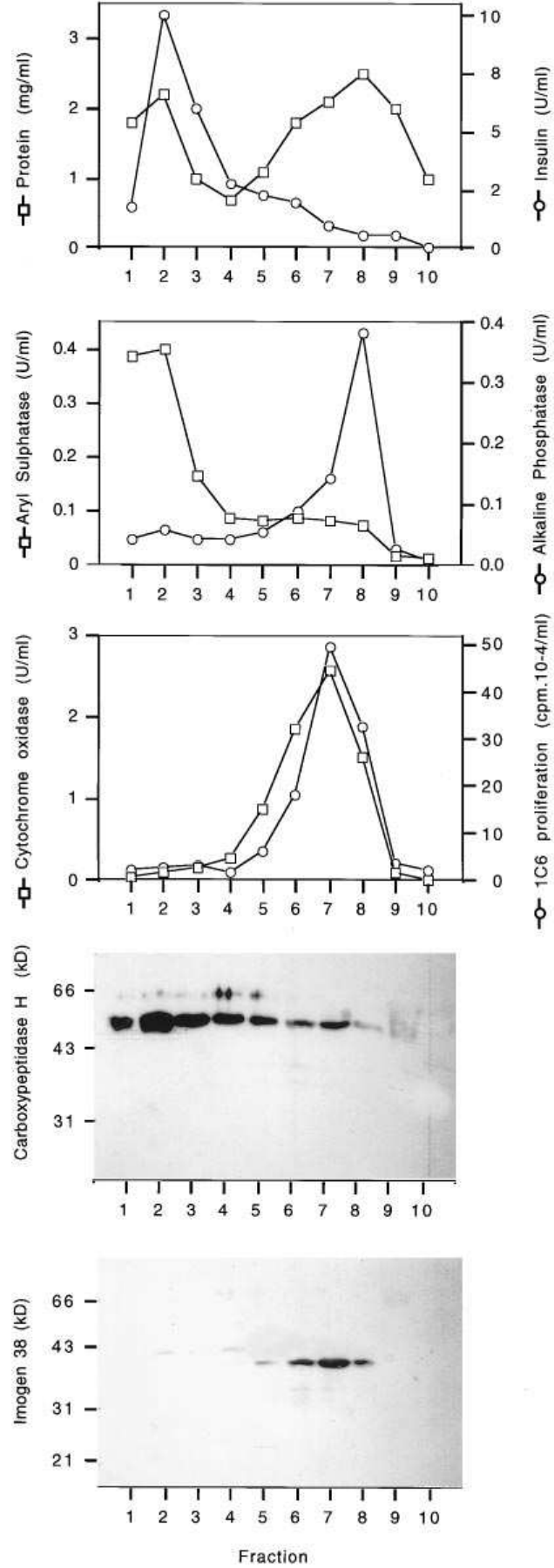

Figure 5. Percoll density gradient centrifugation analysis of the 38$\mathrm{kD}$ antigen in insulinoma tissue. A particulate fraction prepared from insulinoma homogenate at $30,000 \mathrm{~g}$ for $20 \mathrm{~min}$ was subjected to isopycnic density gradient centrifugation and recovered in 10 fractions of decreasing density. Each fraction was assayed for organelle marker proteins and $1 \mathrm{C} 6$ reactivity as indicated on the y-axes; Western blot analyses were performed with rabbit anti-carboxypeptidase $\mathrm{H}$ and affinity-purified guinea pig anti-38-kD protein. Equivalent volumes of each fraction were analyzed in each assay to ensure that the response reflected the distribution of the antigen rather than its specific activity. 
Table I. 1C6 T Cell Proliferative Response to Transfected COS 7 Cells

\begin{tabular}{|c|c|c|c|c|c|}
\hline Fraction & None & Vector alone & Furin & $9 \mathrm{~B} 2$ & $1 \mathrm{C} 2$ \\
\hline Soluble & $141 \pm 31$ & $142 \pm 47$ & $200 \pm 70$ & $128 \pm 32$ & $317 \pm 77$ \\
\hline Particulate & $121 \pm 28$ & $90 \pm 32$ & $113 \pm 35$ & $102 \pm 27$ & $10,476 \pm 1,562$ \\
\hline Controls & PHA $23,915 \pm 5,695$ & 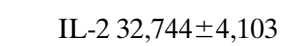 & Medium $112 \pm 49$ & $\mathrm{CMF}$ & \\
\hline
\end{tabular}

Cells were harvested $24 \mathrm{~h}$ after transfection, sonicated in a low-salt buffer, and separated into a soluble and particulate fraction by centrifugation. Results with untransfected and mock-transfected cells are shown together with cells transfected with an unrelated protein (furin), a nontranslated truncated cDNA clone 9B2, and the full-length clone $1 \mathrm{C} 2$. Results are the mean cpm \pm SD of triplicate analyses using $5 \mu \mathrm{g} / \mathrm{ml}$ of antigen protein in the proliferation assay. A Western blot analysis of the same samples is shown in Fig. 6. $C M F$, crude membrane fraction from rat insulinoma.

tion prepared at 3,000 $\mathrm{g}$ for $20 \mathrm{~min}$. Western blot analysis showed the presence of a major immunoreactive $38-\mathrm{kD}$ protein and a minor $60-\mathrm{kD}$ component whose distributions paralleled that of 1C6 reactivity. Marker protein analyses showed that, whereas the distribution of the antigen overlapped with secretory granules, it appeared to be concentrated in organelles of larger size and/or greater density. Its sedimentation behavior was similar to that of cytochrome oxidase, a mitochondrial marker, and differed from that of alkaline phosphatase, a plasma membrane marker, and aryl sulphatase, a marker of lysosomes.

Isopycnic density gradient centrifugation analysis of rat insulinoma tissue using Percoll in isotonic sucrose as the medium (Fig. 5) showed that the major peak of $1 \mathrm{C} 6$ reactivity coincided with the $38-\mathrm{kD}$ immunoreactivity on Western blotting. Both paralleled the distribution of the mitochondrial marker cytochrome oxidase but differed from that of the lysosomal marker, aryl sulphatase, and the secretory granule markers, insulin (determined by immunoassay) or carboxypeptidase $\mathrm{H}$ (determined by Western blotting). The distribution of the antigen overlapped with that of the plasma membrane marker, alkaline phosphatase, though the latter was mostly concentrated in fractions of a lower buoyant density.

Transient transfection of COS 7 cells was achieved using the clone $1 \mathrm{C} 2$ inserted under a cytomegalovirus promoter in the vector pCDNA3. The shorter cDNA clone, 9B2 (Fig. 1), which could be translated in vitro to a protein of lower $M_{\mathrm{r}}$ (33 kD) (Fig. 2), was also analyzed, along with mock-transfected cells and cells transfected with an unrelated protein (furin). Nontransfected, mock-transfected, and 9B2-transfected cells showed background reactivity in the $1 \mathrm{C} 6 \mathrm{~T}$ cell proliferation assay, whereas $1 \mathrm{C} 2$ transfectants produced a response comparable to particulate fractions of rat insulinoma tissue (Table I). Western blot analysis showed the presence of immunoreactive protein in 1C2-transfected cells (Fig. 6), which was indistinguishable in size from the native rat insulinoma protein (38 $\mathrm{kD}$ ) and clearly smaller in size than the product of translation of the corresponding cRNA in vitro (44 kD) (Fig. 3). Control cells showed much smaller amounts of a $38-\mathrm{kD}$ immunoreactive protein, which, in any case, appeared in the soluble fraction. The low reactivity in controls appears to relate to the antigen content rather than to a lack of species cross-reactivity, since the 1C6 $\mathrm{T}$ cell clone is responsive to the antigen in the human islets (Roep, B. O., and J. C. Hutton, unpublished findings).

The appearance of Western blot immunoreactivity in the soluble fraction of 1C2-transfected cells in the absence of significant $1 \mathrm{C} 6 \mathrm{~T}$ cell reactivity was an unexpected observation. A mixture of the particulate fraction from 1C2-transfected cells with the soluble fraction of nontransfected cells $(10 \mu \mathrm{g}$ each) induced the same proliferative response as the particulate fraction alone. Mixture of the soluble fraction from the 1C2-transfected cells with the particulate fraction of nontransfected cells failed to produce a proliferative response. Thus, it appeared unlikely that the soluble fraction contained an inhibitor of the $\mathrm{T}$ cell proliferation assay or that the presence of membranes per se enhanced the presentation or $\mathrm{T}$ cell reactivity to the antigen.

Indirect immunofluorescence microscopy of the 1C2-transfected COS 7 cells revealed a distinctive pattern of antibody reactivity in positively transfected cells associated with large intracellular structures that ranged in morphology from discrete ovoid or doughnut-shaped organelles to long tubular elements with occasional bifurcation (Fig. 7). Such structures are characteristic of mitochondria in COS 7 cells, and it was shown that the antibody to $38 \mathrm{kD}$ colocalized with an mAb to a human 65-kD mitochondrial protein (2D1/82; Biogenesis Ltd.). There was little or no anti-38-kD antibody reactivity on any of the control transfectants (data not shown), consistent with the low reactivity of the antisera on Western blots (Fig. 6) and the negative response in the 1C6 $\mathrm{T}$ cell proliferation assay (Table I). The specific pattern of anti-38-kD immunofluorescence was not observed with nonimmune serum or preabsorbed antibody.

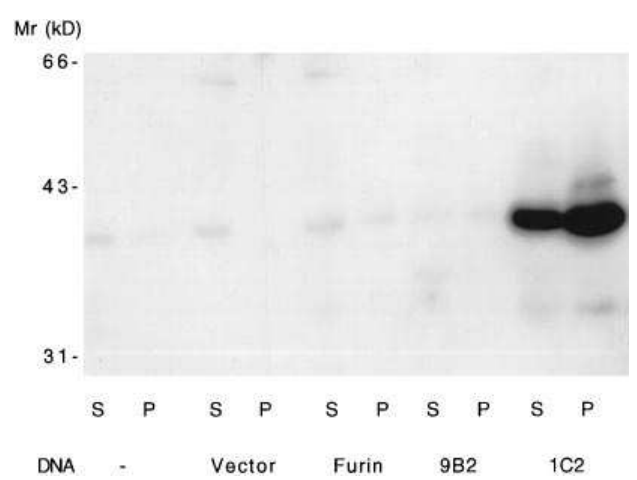

Figure 6. Expression of $38-\mathrm{kD}$ cDNA in transiently transfected COS 7 cells. Transfected cells were cultured for $24-26 \mathrm{~h}$, sonicated in a low-salt buffer, and separated into a soluble $(S)$ and particulate $(P)$ fraction by centrifugation. Results with untransfected and mocktransfected cells are shown together with cells transfected with an unrelated protein (furin), a truncated cDNA clone 9B2, and the fulllength clone $1 \mathrm{C} 2$. Samples were separated on $12.5 \%$ SDS-PAGE gels for blotting (20 $\mu \mathrm{g}$ protein) and assayed in parallel for 1C6 $\mathrm{T}$ cell reactivity (Table I). 

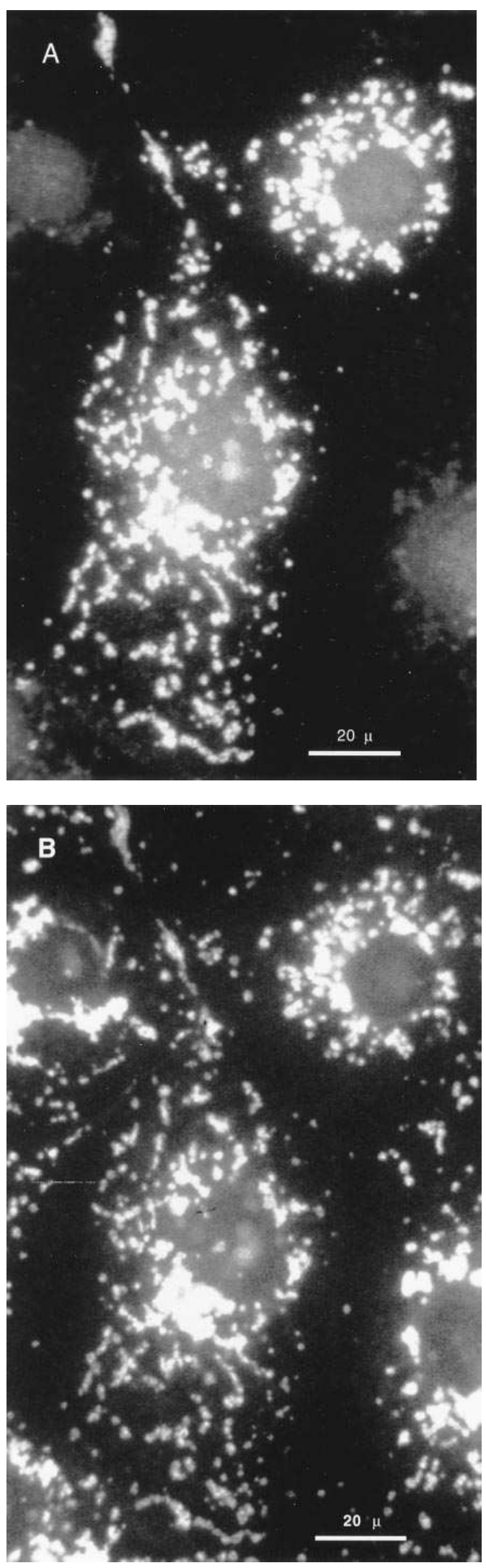

Figure 7. Immunohistochemical localization of the $38-\mathrm{kD}$ antigen. COS 7 cells were transiently transfected with clone $1 \mathrm{C} 2$ and developed with rabbit anti-38-kD antibody $(A)$ and a mouse $\mathrm{mAb}$ to a human mitochondrial protein $(B)$. The pattern of immunoreactivity in the positively transfected cells coincides with the mitochondrial marker.
Tissue distribution of the $38-k D$ antigen. Northern blot analyses of various mouse tissues (Fig. 8) revealed a single 1.5$\mathrm{kb}$ mRNA that was widely distributed but variable in its level of expression. A second minor component of $2.4 \mathrm{~kb}$ was evident in kidney and liver tissue. Probes spanning the epitopeencoding region gave similar results to those shown with the major segment of the open reading frame, indicating that the mRNA that hybridized was related to the specific antigen in question. Phosphorimager quantitation showed that the signal generated with the $1 \mathrm{C} 2$ probe ranged from 1 to $4 \%$ of that with an actin probe of similar specific radioactivity at the same level of stringency of hybridization and washing (data not shown). Analysis of a series of mouse cell lines showed a higher abundance of the mRNA in $\beta$ TC3 insulinoma cells relative to $\alpha \mathrm{TC} 2$ glucagonoma cells, consistent with the results of the subtractive hybridization procedure used to isolate the cDNA fragment initially (26). The mRNA was also demonstrated in the pituitary corticotroph cell line AtT20.

The distribution of the protein antigen was initially investigated in a series of tissue culture cell lines (Fig. 9, Table II) using sonication to disrupt the tissue and centrifugation to prepare a soluble and particulate fraction. As in the case of insulinoma tissue, $1 \mathrm{C} 6 \mathrm{~T}$ cell reactivity was associated with a particulate fraction. The growth hormone pituitary cell line GH4 and the pituitary corticotroph line AtT20 induced a marked 1C6 proliferative response, as did the insulinoma cell line $\beta$ TC3. The glucagonoma cell $\alpha \mathrm{TC} 2$ and the liver cell line BRL showed lower levels of expression. Western blot analyses, performed in parallel, showed a predominant $38-\mathrm{kD}$ band that was associated mainly with the particulate fraction. There was a good correlation between the intensity of the reaction on the Western blot and the magnitude of the proliferative response evoked by these fractions.

Analysis of different mouse tissues using the1C6 T cell proliferation assay (Table III) showed the presence of the antigen in a particulate fraction from testes, kidney, and liver but not in heart and skeletal muscle. Intermediate responses were demonstrated in lung, spleen, brain, and gastric fundus. When tested at a lower concentration $(1 \mu \mathrm{g} / \mathrm{ml})$, only the testes sample produced a response (data not shown), suggesting that most responses were close to the limit of detection. Western blot analyses performed on the same samples showed the pres-

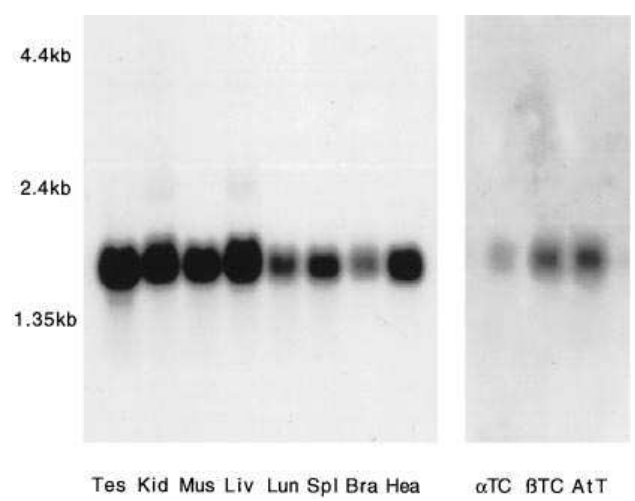

Figure 8. Northern blot analyses. Poly $\mathrm{A}^{+}$mRNA samples $(5 \mu \mathrm{g})$ prepared from the indicated mouse tissues and cell lines were hybridized to a probe prepared from a 955-bp fragment from clone 1C2. Sample sizes were adjusted in each case to give an equivalent signal to an actin probe. 


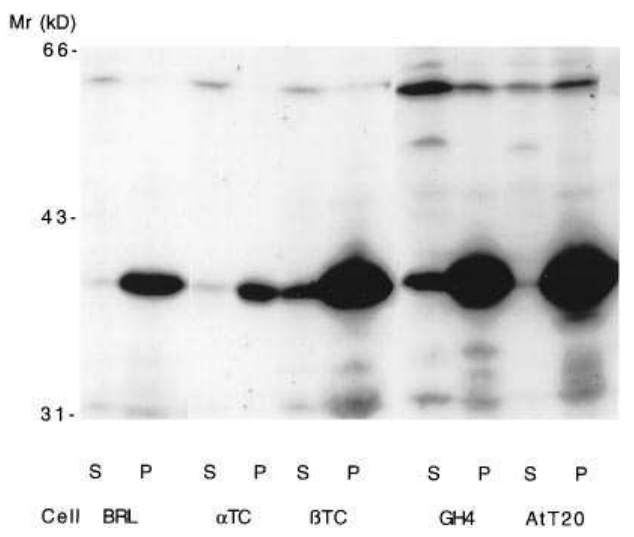

Figure 9. Western blot analysis of the $38-\mathrm{kD}$ antigen in mouse tissue culture cell lines. Cells were harvested when semiconfluent, sonicated in a low-salt buffer, and separated into a soluble $(S)$ and particulate $(P)$ fraction by centrifugation. Samples were separated on $12.5 \%$ SDS-PAGE gels for blotting (20- $\mu \mathrm{g}$ protein) and assayed in parallel for 1C6 T cell reactivity (Table II).

ence of a 38-kD protein in all tissues (Fig. 10). This was lowest in the case of skeletal muscle and heart, which might account for the low $\mathrm{T}$ cell reactivity to these tissues. Immunoreactive proteins other than the $38-\mathrm{kD}$ band were evident, notably a 33$\mathrm{kD}$ protein in liver, kidney, and muscle and a $60-\mathrm{kD}$ component in muscle, but were not investigated further.

\section{Discussion}

The cDNA cloned in these experiments appears to encode a normal mouse protein that represents a precursor form of a native $38-\mathrm{kD}$ antigenic target of the human diabetic $\mathrm{CD}^{+} \mathrm{T}$ cell clone 1C6. Database searching at either the nucleotide or amino acid level and analysis for conserved protein motifs failed to reveal the identity of the protein or to provide clues to its biochemical properties or function. The previously reported

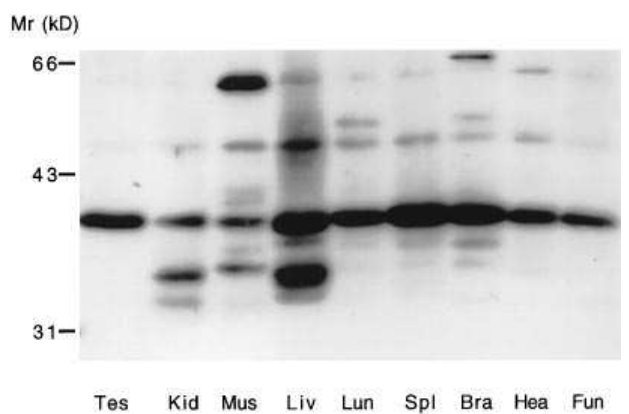

Figure 10. Western blot analysis of the $38-\mathrm{kD}$ antigen in different mouse tissues. Tissues were pulverized in liquid nitrogen and then sonicated in a low-salt buffer, and a particulate fraction was recovered by centrifugation. Samples were separated on $12.5 \%$ SDSPAGE gels for blotting (20- $\mu$ g protein) and assayed in parallel for 1C6 T cell reactivity (Table III).

homology of the 70-aa probe sequence with the bacterial superantigens Streptococcus pyogenes exotoxin A and Staphylococcus entertoxin B ( $\sim 25 \%$ identity over 60 aa) (26) did not extend beyond the immediate region originally identified. Likewise, homologies of the 11-aa minimal epitope with the prolactin receptor and lens $\beta$-crystallin were not borne out by the longer sequence. Attempts to define common linear epitopes by alignment of the amino sequence with GAD, carboxypeptidase $\mathrm{H}$, heat shock protein 60 , mycobacterial heat shock protein 65 , and peripherin proved unsuccessful. It is concluded that the protein has not been previously identified at the structural level. In the absence of any functional information, it is given the name imogen 38 (islet mitochondrial antigen of $38 \mathrm{kD}$ ).

Imogen 38 could generally be distinguished from other 38$\mathrm{kD}$ diabetic autoantigens previously described. Its subcellular localization and sequence differ from those of the nuclear transcription factor Jun B, which was cloned from an islet cell expression library by autoantibody screening (24). The observa-

Table II. 1C6 T Cell Proliferative Response to Mouse Tissue Culture Cell Lines

\begin{tabular}{|c|c|c|c|c|c|}
\hline & BRL & $\alpha \mathrm{TC} 2$ & $\beta \mathrm{TC} 3$ & GH4 & AtT20 \\
\hline Soluble & $33 \pm 12$ & $226 \pm 219$ & $48 \pm 3$ & $171 \pm 14$ & $217 \pm 165$ \\
\hline Particulate & $2,653 \pm 261$ & $5,325 \pm 2,290$ & $7,851 \pm 1,453$ & $24,798 \pm 3,533$ & $17,986 \pm 5,560$ \\
\hline Controls & PHA $43,973 \pm 11,371$ & IL-2 17,808 $\pm 2,926$ & Medium $58 \pm 28$ & CMF $29,770 \pm 3,031$ & \\
\hline
\end{tabular}

Cells were harvested when semiconfluent, sonicated in a low-salt buffer, and separated into a soluble and particulate fraction by centrifugation. Results are the mean cpm \pm SD of triplicate analyses using $5 \mu \mathrm{g} / \mathrm{ml}$ of antigen protein in the proliferation assay. A Western blot analysis of the same samples is shown in Fig. 9. $C M F$, crude membrane fraction from rat insulinoma.

Table III. 1C6 T Cell Proliferative Response to Membrane Preparations of Different Mouse Tissues

\begin{tabular}{lccccccc}
\hline \multicolumn{1}{c}{ Testis } & Kidney & $\begin{array}{c}\text { Skeletal } \\
\text { muscle }\end{array}$ & Liver & Lung & Spleen & Brain & $\begin{array}{c}\text { Cardiac } \\
\text { muscle }\end{array}$ \\
\hline $5,860 \pm 276$ & $3,910 \pm 2,892$ & $114 \pm 58$ & $2,859 \pm 410$ & $994 \pm 220$ & $4,722 \pm 924$ & $1,326 \pm 715$ & $110 \pm 18$ \\
fundus
\end{tabular}

Results are the mean cpm \pm SD of triplicate analyses using $5 \mu \mathrm{g} / \mathrm{ml}$ of antigen protein in the proliferation assay. A Western blot analysis of the same samples is shown in Fig. 10 and related Northern blot analyses in Fig. 8. $C M F$, crude membrane fraction from rat insulinoma. 
tion that imogen 38 is derived from a precursor of $44 \mathrm{kD}$ and the fact that it has no $\mathrm{N}$-glycosylation consensus sequences distinguish it from the $37-$ and $40-\mathrm{kD}$ antigens described by Christie and colleagues (7), which are both derived from glycoproteins of $64 \mathrm{kD}$. The lack of $\mathrm{N}$-glycosylation and different solubility characteristics also differentiate between imogen 38 and the amphipathic $38-\mathrm{kD}$ molecule identified in islet immunoprecipitation studies using diabetic autoantisera $(22,23)$. More subtle relationships, such as the possession of common conformational epitopes, cannot be presently excluded, and serological studies are being performed using the purified recombinant imogen 38 to evaluate the incidence, prevalence, and magnitude of immune responses to this antigen to clarify this issue.

The structural evidence that suggested mitochondrial localization of the encoded protein was strongly supported by immunofluorescence microscopy of transfected COS 7 cells using an antibody generated to the recombinant protein and by differential and Percoll density gradient centrifugation analyses of the native antigen in insulinoma tissue. Previous investigations based on analysis of discontinuous Nycodenz density gradients of insulinoma homogenates had indicated that 1C6 T cell reactivity was associated with ISGs (18). Although granule-enriched fractions from Nycodenz gradients contain only a small proportion of all the mitochondria of the cell, the specific activity of mitochondrial marker proteins within them is comparable to fractions containing the bulk of the mitochondria, since the latter also contain most of the endoplasmic reticulum proteins. This, combined with the difficulty of obtaining reliable estimates of the initial content and recoveries of the antigen because of the nonlinearity of the $\mathrm{T}$ cell proliferation assay, made it impossible to distinguish granule from mitochondrial localization under these circumstances. The present studies, which used a different density gradient system and were backed up by Western blotting analyses, were unequivocal and showed that the mitochondrion is the major site of imogen 38 localization in the normal pancreatic $\beta$ cell.

The presence of a leader sequence of largely hydrophobic character punctuated by basic amino acid residues indicates that imogen 38 is initially imported into the mitochondrion via a voltage-dependent and HSP70-dependent process (41). Cleavage by the matrix-processing peptidase complex at the first consensus sequence $\mathrm{Arg} \mathrm{Asp}_{25}$ would produce a protein of $41 \mathrm{kD}$ with an estimated $\mathrm{pI}$ of 8.0 and expose an $\mathrm{NH}_{2}$-terminal hydrophobic stretch of 14 amino acids (residues 26-39). Within the paradigm of the endosymbiotic origin of mitochondria, this could constitute the equivalent of a bacterial signal sequence and direct the protein from the matrix through the inner mitochondrial membrane, where it could be processed further by IMP1 or the octapeptidyl peptidase-like enzyme (43) to a soluble protein of $39.5 \mathrm{kD}$ and $\mathrm{pI}$ of 7.6. Alternatively, the precursor could be processed by the matrix-processing peptidase complex after the $\operatorname{Arg} \operatorname{Thr}_{41}$ (39.5 kD, pI 7.6), Arg $\mathrm{His}_{48}$ (38.6 kD, pI 7.5), or $\operatorname{Arg~Ser}_{54}(38.0 \mathrm{kD}$, pI 7.1). The last product fits best with the migration of the rat, mouse, or human antigen on SDS-PAGE and with the pI of the native rat insulinoma antigen $(7.0 \pm 0.1, n=8)$ determined with the 1C6 $\mathrm{T}$ cell proliferation assay by isoelectric focusing in $8 \mathrm{M}$ urea and 4\% NP-40 (Arden, S. D., B. O. Roep, and J. C. Hutton, unpublished findings). The 55-384 sequence, however, contains no hydrophobic stretches longer than 9 aa, and thus the association of the antigen with membranes as detected pre- viously in the $1 \mathrm{C} 6 \mathrm{~T}$ cell proliferation assay (18) is likely to occur by a process other than membrane spanning. The finding that transient overexpression of the antigen in COS 7 cells results in an antigenic form that can be solubilized by sonication suggests that its interaction with membrane structure may depend on other anchored proteins or posttranslational modification of the protein. These experiments also revealed that the solubilized antigen is a poorer stimulus for 1C6 T cell proliferation than the particulate form, a phenomenon which biases interpretation of localization studies based on $\mathrm{T}$ cell proliferation data to favor the conclusion that the antigen is exclusively membrane associated. These questions are likely to be resolved by structural analysis of purified forms of the native antigen and studies of its biosynthesis and interaction with other cellular constituents. Such studies will be facilitated by the availability of antibodies that were developed in the current experimental series.

Although imogen 38 appeared to be more abundant in $\beta$ cells than in $\alpha$ cells, its tissue distribution was broad and consistent with is being a housekeeping gene or a structural component common to all oxidative tissues. Although the existence of tissue-specific isoforms of the antigen could not be ruled out, the majority would appear to possess the antigenic epitope recognized by the T cell clone 1C6. On these grounds, it is unlikely that imogen 38 is a primary target for cellular autoimmune attack in type 1 diabetes. This does not, however, preclude it from playing an important pathological role as a target for bystander autoimmune attack and a contributor to insulitis. Indeed, it may be argued that such a role is more consistent with a mitochondrial protein that is neither accessible nor easily presentable to the cellular or humoral arm of the immune system without tissue disruption or dysfunction. Nevertheless, mitochondrial antigens with a similarly broad tissue distribution are implicated in other tissue-specific autoimmune diseases, notably, the ADP/ATP transporter of the inner mitochondrial membrane in autoimmune myocarditis and dilated cardiomyopathy (44), the mitochondrial matrix chaperonin heat shock protein 60 (the mammalian homologue of mycobacterial HSP65) in rheumatoid arthritis, type-1 diabetes and myositis (45-47), and the inner mitochondrial membrane 2-oxoacid multienzyme complexes in primary biliary cirrhosis $(48,49)$. In the latter instance, immunohistological studies with autoantibodies and mAbs to the immunodominant E2 component (dihydrolipoyl acetyltransferase) reveal immunoreactive structures not only in mitochondria but also in the apical region of the biliary epithelium and the ductal lumen. Moreover, such reactivity is only evident in diseased tissue, which raises the possibility that the E2 subunit is actually mistargeted to the secretory pathway in response to inflammation. The fact that proteins like E2 and imogen 38 probably need to interact with cytosolic chaperonins of the HSP70 family to be directed to mitochondria (41), and that they possess potential or ancestral "signal peptide"-like structures within their mitochondrial targeting sequences, suggests a possible molecular mechanism by which a sequestered organellar protein may be redirected to the secretory pathway and gain access to the cell surface or compartments involved in antigen presentation. Such a phenomenon probably occurs with a number of different mitochondrial proteins (e.g., 50-52) and could account for the apparent tissue specificity of an autoimmune attack directed at otherwise widely distributed tissue antigens. There is no direct evidence, at the moment, for such a mechanism either in the 
case of E2 or imogen 38, which emphasizes the need to understand more of the cell biology of imogen 38 in both the normal and prediabetic islet and the mechanism by which it is presented to T cells in vivo. Such questions can be more easily addressed now that imogen 38 has been cloned and recombinant antigens and antibodies have been generated. These reagents will likewise facilitate investigations, both clinical and experimental, of the importance of this particular antigen to the pathogenesis of type 1 diabetes and examination of its potential as a diagnostic marker or therapeutic agent.

\section{Acknowledgments}

We thank Dr. Gerhard Christofori (Biozentrum, Vienna, Austria) for the provision of the pSVSPORT Rip Tag insulinoma cDNA library and Dr. Don Healey and Dr. Anne Cooke (Department of Pathology, University of Cambridge, UK) for helpful discussions.

This work was supported by the Wellcome Trust, British Diabetic Association, Juvenile Diabetes Foundation International, and Diabetes Fonds Nederland. P. I. Neophytou was supported by the Cambridge Commonwealth Trust and the Fishmonger's Company of London Mark Quested Exhibition; E. F. Usac was supported by the Fundació Clinic, Barcelona; and B. O. Roep is a fellow of the Royal Academy of Arts and Sciences, The Netherlands.

\section{References}

1. Pietropaolo, M., and G. S. Eisenbarth. 1994. Molecular targets of autoimmunity in type 1 diabetes. In Molecular Biology of Diabetes. I. Autoimmunity and Genetics: Insulin Secretion and Synthesis. B. Draznin and D. LeRoith, editors. Humana Press, Totowa, NJ. 1-33.

2. Palmer, J. P., C. M. Asplin, P. Clemons, K. Lyen, O. Tatpati, P. K. Raghu, and T. L. Paquette. 1983. Insulin antibodies in insulin dependent diabetics before insulin treatment. Science (Wash. DC). 222:1337-1339.

3. Castano, L., E. Russo, L. Zhou, M. A. Lipes, and G. S. Eisenbarth. 1991. Identification and cloning of a granule autoantigen (carboxypeptidase $\mathrm{H}$ ) associated with type I diabetes. J. Clin. Endocrinol. \& Metab. 73:1197-1201.

4. Christgau, S., H. J. Aanstoot, H. Schierberg, K. Begley, S. Tullin, K. Hejnaes, and S. Baekkeskov. 1992. Membrane anchoring of the autoantigen $\mathrm{GAD}_{65}$ to microvesicles in pancreatic $\beta$-cells by palmitoylation in the $\mathrm{NH}_{2}$-terminal domain. J. Cell Biol. 118:309-320.

5. Pietropaolo, M., L. Castano, S. Babu, R. Buelow, Y. L. S. Kuo, S. Martin, A. Martin, A. C. Powers, M. Prochazka, J. Naggert, et al. 1993. Islet cell autoantigen $69 \mathrm{kD}$ (ICA69): molecular cloning and characterization of a novel diabetes-associated autoantigen. J. Clin. Invest. 92:359-371.

6. Rabin, D. U., S. M. Pleasic, J. A. Shapiro, H. Yoo-Warren, J. Oles, J. M. Hicks, D. E. Goldstein, and P. M. M. Rae. 1994. Islet cell antigen 512 is a diabetes-specific islet autoantigen related to protein tyrosine phosphatases. J. Immunol. 152:3183-3188.

7. Christie, M. R., J. A. Hollands, T. J. Brown, B. K. Michelsen, and T. L. Delovitch. 1993. Detection of pancreatic islet 64,000 $M_{\mathrm{r}}$ autoantigens in insulindependent diabetes distinct from glutamate decarboxylase. J. Clin. Invest. 92: 240-248.

8. Boitard, C., M. C. Villa, C. Becourt, H. P. Gia, C. Huc, P. Sempe, and M. M. Portier. 1992. Peripherin: an islet antigen that is cross-reactive with nonobese diabetic mouse class II gene products. Proc. Natl. Acad. Sci. USA. 89:172-176.

9. Atkinson, M. A., D. L. Kaufman, L. Cambell, K. A. Gibbs, S. C. Shah, D.-F. Bu, M. G. Erlander, A. J. Tobin, and N. K. Maclaren. 1992. Response of peripheral blood mononuclear cells to glutamate decarboxylase in insulindependent diabetes. Lancet. 339:458-459.

10. Diaz, J.-L., J. Ways, and P. Hammonds. 1992. T-lymphocyte lines specific for glutamic acid decarboxylase (GAD) the $64 \mathrm{~K} \beta$-cell antigen of IDDM. Diabetes 41:118-121.

11. Kaufman, D., M. Clare-Salzler, J. Tian, T. Forsthuber, G. S. P. Ting, P. Robinson, M. A. Atkinson, E. E. Sercarz, A. J. Tobin, and P. V. Lehman. 1993. Spontaneous loss of T-cell tolerance to glutamic acid decarboxylase in murine insulin-dependent diabetes. Nature (Lond.). 366:69-72.

12. Tisch, R., X.-D. Yang, S. M. Singer, R. S. Liblau, L. Fugger, and H. O. McDevitt. 1993. Immune response to glutamic acid decarboxylase correlates with insulitis in non-obese diabetic mice. Nature (Lond.). 366:72-75.

13. Haskins, K., M. Portas, B. Bergman, K. Lafferty, and B. Bradley. 1989. Pancreatic islet-specific T-cell clones from nonobese diabetic mice. Proc. Natl. Acad. Sci. USA. 86:8000-8004.

14. Bieg, S., E. M. Bailyes, N. Yassin, J. Amann, L. Herberg, A. M. Mc-
Gregor, W. A. Scherbaum, and J. P. Banga. 1993. A multiplicity of protein antigens in subcellular fractions of rat insulinoma tissue are able to stimulate $\mathrm{T}$ cells obtained from non-obese diabetic mice. Diabetologia. 36:385-390.

15. Gelber, C., L. Paborsky, S. Singer, D. McAteer, R. Tisch, C. Jolicoeur, R. Buelow, H. McDevitt, and C. G. Fathman. 1994. Isolation of nonobese diabetic mouse $\mathrm{T}$-cells that recognize novel autoantigens involved in the early events of diabetes. Diabetes. 43:33-39.

16. Roep, B. O., A. A. Kallan, G. Duinkerken, S. A. Arden, J. C. Hutton, G. J. Bruining, and R. R. P. de Vries. 1995. T-cell reactivity to $\beta$-cell membrane antigens associated with $\beta$-cell destruction in type 1 diabetes. Diabetes. 44:278283.

17. Bergman, B., and K. Haskins. 1994. Islet-specific T-cell clones from the NOD mouse respond to beta-granule antigen. Diabetes. 43:197-203.

18. Roep, B. O., S. D. Arden, R. R. P. de Vries, and J. C. Hutton. 1990. $\mathrm{T}$-cell clones from a type-1 diabetes patient respond to insulin secretory granule proteins. Nature (Lond.). 345:632-634.

19. Healey, D., P. Ozegbe, S. D. Arden, P. Chandler, J. C. Hutton, and A. Cooke. 1995. In vivo activity and in vitro specificity of $\mathrm{CD}^{+} \mathrm{Th} 1$ and $\mathrm{Th} 2$ cells derived from the spleens of diabetic NOD mice. J. Clin. Invest. 95:29792985

20. Chang, J. C. C., L. G. Linarelli, J. A. Laxer, K. J. Froning, L. L. Caralli, S. W. Brostoff, and D. J. Carlo. 1995. Insulin secretory granule specific T cell clones in human IDDM. J. Autoimmun. 8:221-234.

21. Roep, B. O., A. A. Kallan, W. L. W. Hazenbos, G. J. Bruining, E. M. Bailyes, S. D. Arden, J. C. Hutton, and R. R. P. de Vries. 1991. T-cell reactivity to $38 \mathrm{kD}$ insulin-secretory-granule protein in patients with recent-onset type 1 diabetes. Lancet. 337:1439-1441.

22. Baekkeskov, S., J. H. Neilsen, B. Marner, T. Bilde, J. Luddvigsson, and Å. Lernmark. 1982. Autoantibodies in newly diagnosed diabetic children immunoprecipitate human pancreatic islet cell proteins. Nature (Lond.). 298:167169.

23. Aanstoot, H. J., B. O. Roep, R. R. P. de Vries, M. R. Williamson, J. Ludvigsson, and S. Baekkeskov. 1991. Humoral and cellular response to a $38 \mathrm{kD}$ is let cell autoantigen in type I diabetes. Diabetes. 40:898. (Abstr.)

24. Honeyman, M. C., D. S. Cram, and L. C. Harrison. 1993. Transcription factor jun-B is target of autoreactive T-cells in IDDM. Diabetes. 42:626-630.

25. Ko, I. Y., H. S. Jun, G. S. Kim, and J. W. Yoon. 1994. Studies on autoimmunity for initiation of Beta-cell destruction. X. Delayed expression of a membrane-bound islet cell-specific $38 \mathrm{kD}$ autoantigen that precedes insulitis and diabetes in the diabetes-prone BB rat. Diabetologia. 37:460-465.

26. Neophytou, P. I., B. O. Roep, S. D. Arden, E. M. Muir, G. Duinkerken, A. Kallan, R. R. P. de Vries, and J. C. Hutton. 1995. Subtractive expression cloning of the epitope of a $38 \mathrm{kD}$ autoantigen recognised by T-cells from an insulin dependent diabetic patient. Proc. Natl. Acad. Sci. USA. In press.

27. Sambrook, J., E. F. Fritsch, and T. Maniatis. 1989. Molecular Cloning: A Laboratory Manual. Cold Spring Harbor Laboratory Press, Cold Spring Harbor, NY. pp.

28. Neophytou, P. I., E. M. Muir, and J. C. Hutton. 1995. A subtractive cloning approach to the identification of mRNAs specifically expressed by pancreatic beta cells. Diabetes. In press.

29. Doren, K. V., D. Hanahan, and Y. Gluzman. 1984. Infection of eukaryotic cells by helper-independent adenoviruses. Early region-1 is not obligatory for integration of viral DNA. J. Virol. 50:606-614.

30. Hutton, J. C., G. Christofori, W. Y. Chi, U. Edman, P. C. Guest, D. Hanahan, and R. B. Kelly. 1993. Molecular cloning of mouse pancreatic islet R-cadherin: differential expression in endocrine and exocrine tissue. Mol. Endocrinol. 7:1151-1160.

31. Brun, Y. V., R. Breton, and J. Lapointe. 1991. Large scale sequencing projects using rapidly prepared double-stranded plasmid DNA. J. DNA Sequencing and Mapping. 1:285-289.

32. Smith, D. B., and K. S. Johnson. 1988. Single step purification of polypeptides in Escherichia coli as fusions with glutathione $S$-transferase. Gene (Amst.). 67:31-40.

33. Bohmann, D., and R. Tijan. 1989. Biochemical analysis of transcriptional activation by Jun. Differential activity of c- and v-JUN. Cell. 59:709-717.

34. Hutton, J. C., E. J. Penn, and M. Peshavaria. 1982. Isolation and characterisation of insulin secretory granules from a rat islet cell tumour. Diabetologia. 21:224-229.

35. Cooperstein, S. J., and A. Lazarow. 1951. A microspectrophotometric method for the determination of cytochrome oxidase. J. Biol. Chem. 189:665670.

36. Roy, A. B. 1953. The sulphatase of ox liver. I. The complex nature of the enzyme. Biochem. J. 53:12-15.

37. Bowers, G. N., and R. B. McComb. 1975. Measurement of total alkaline phosphatase activity in human serum. Clin. Chem. 21:1988-1995.

38. Guest, P. C., C. J. Rhodes, and J. C. Hutton. 1989. Regulation of the biosynthesis of insulin-secretory-granule proteins: co-ordinate translational control is exerted on some, but not all, granule matrix constituents. Biochem. J. 257: 431-437.

39. Chirgwin, J. M. A. E. Przbyla, R. J. McDonald, and W. J. Rutter. 1979. Isolation of biologically active RNA from sources enriched in ribonuclease. Biochemistry. 18:5294-5299. 
40. Hutton, J. C., M. Peshavaria, C. F. Johnston, M. Ravazzola, and L. Orci. 1988. Immunolocalization of betagranin: a chromogranin A-related protein of the pancreatic B-cell. Endocrinology. 122:1014-1020.

41. Segui-Real, B., R. A. Stewart, and W. Neupert. 1992. Transport of proteins into the various subcompartments of mitochondria. FEBS Lett. 313:2-7.

42. Wang, Z., and D. D. Brown. 1991. A gene expression screen. Proc. Natl. Acad. Sci. USA. 88:11505-11509.

43. Hendrick, J. P., P. E. Hodges, and L. E. Rosenberg. 1989. Survey of amino-terminal proteolytic cleavage sites in mitochondrial precursor proteins. Leader peptides cleaved by two matrix proteases share a three amino acid motif. Proc. Natl. Acad. Sci. USA. 86:4056-4060.

44. Schultheiss, H. P., K. Schultze, R. Schauer, R. Witzenbichler, and B. E. Strauer. 1995. Antibody-mediated imbalance of myocardial energy metabolism—a causal factor in cardiac failure. Circulation Res. 76:64-72.

45. Elias, D., D. Markovits, T. Reshef, R.v.d. Zee, and I. R. Cohen. 1990. Induction and therapy of autoimmune diabetes in the non-obese diabetic (NOD/Lt) mouse by a $65-\mathrm{kD}$ heat shock protein. Proc. Natl. Acad. Sci. USA. 87:1576-1580.

46. Hohlfeld, R., and A. G. Engel. 1992. Expression of $65 \mathrm{kD}$ heat-shock proteins in the inflammatory myopathies. Ann. Neurol. 32:821-823.
47. Yang, X. D., and U. Fiege. 1992. Heat-shock proteins in autoimmune disease. From causative antigen to specific therapy. Experientia (Basel). 48:650656

48. Bjorkland, A., and T. H. Totterman. 1994. Is primary biliary cirrhosis an autoimmune disease? Scand. J. Gastroenterol. 29:32-39.

49. Vandewater, J., A. Ansari, T. Prindiville, R. L. Coppel, N. Ricalton, B. L. Kotzin, S. J. Liu, T. E. Roche, S. M. Krams, S. Munoz, and M.E. Gershwin. 1995. Heterogeneity of autoreactive T cell clones specific for the E2 component of the pyruvate dehydrogenase complex in primary biliary cirrhosis. $J$. Exp. Med. 181:723-733.

50. Ansari, A. A., Y. C. Wang, D. J. Danner, M. B. Gravanis, A. Mayne, N. Neckelmann, K. W. Sell, and A. Herskowitz. 1991. Abnormal expression of histocompatibility and mitochondrial antigens by cardiac tissue from patients with myocarditis and dilated cardiomyopathy. Am. J. Pathol. 139:337-354.

51. Brudzynski, K. 1993. Insulitis-caused redistribution of heat shock protein HSP60 inside beta cells correlates with induction of HSP60 autoantibodies. Diabetes. 42:908-913.

52. Sloan, I. S., P. M. Horowitz, and J. M. Chirgwin. 1994. Rapid secretion by a non-classical pathway of overexpressed mammalian mitochondrial rhodanese. J. Biol. Chem. 269:27625-27630. 